\title{
Paul Williams
}

\section{Writing the memoir of self-erasure: A practice-led exploration of constructing and deconstructing the coloniser- who-refuses}

\begin{abstract}
Writing memoir entails more than researching, recording and constructing a past 'self'. The act of writing forces a set of critical strategies similar to that of writing a fictional work: there is a problem to be solved, narrative choices to be made, a theory to be tested. The idea of how the past is accessed, reconstructed, researched and re-experienced is also problematic. My recent memoir, Soldier Blue (2008) poses the usual autobiographical problem - 'Who am I?' - but further attempts to interrogate and analyse how this 'I' is constructed, and uses narrative strategies such as the conflation of characters and events, a framing device/ use of an outside narrator, and the constant destabilisation of the idea of a retrievable past in order to solve this problem. The protagonist of Soldier Blue has been created by his society (1960s and 1970s Rhodesia) as a colonial 'white male' with a particular propagandised national identity and agenda. In this paper, I explain the narrative methods used to help me deconstruct this 'self' and trace the paths that lead him out of this labyrinth to become Albert Memmi's 'coloniser who refuses' (Memmi 1990:106). Further, I discuss how in making certain narrative choices in writing this memoir, the boundaries of fiction and non-fiction are blurred, and that in order to create a cohesive narrative, fictional techniques are used that apparently sacrifice historical and factual integrity for the achievement of other aims - that of achieving the emotional truth of the memory/event ... and that of liberating the 'I' or 'self' from the confines of gender/race/class. Keywords: memoir, the-coloniser-who-refuses, self
\end{abstract}

\section{Fact and fiction}

Writers and readers as well as consumers of reality shows and news broadcasts insist on believing that there is a firm line between fiction and non-fiction, and this line is crossed at our peril. Witness for example the furore on Oprah concerning James Frey's memoir A Million Little Pieces and his forced public recant for the cardinal crime of fictionalising sections of the narrative (Unattributed 2006). We partition our bookstores and our university literature courses into these tight sections: Fiction; Non-Fiction; Creative Non-Fiction; Autobiography; Biography; Memoir; Real Crime. On the 'factual' side of this line, we demand accountability to history and to truth. On the 'fictive' side, we don't.

When I began writing my 'memoir', Soldier Blue, I believed it was firmly on the factual side of the line. I believed that what I was doing was telling the 
truth, as honestly as I could, about my experiences growing up as a white settler in Rhodesia (now Zimbabwe). Although the memoir had been brewing in me for twenty years in various forms, an editorial in a British newspaper in 2007 precipitated its realisation. Graham Boynton of the Daily Telegraph (2007), echoing a common misconception of the colonial history of Zimbabwe/Rhodesia, and appalled by the atrocities of the Mugabe regime and the deterioration in human rights in that country, claimed that Zimbabwe had been better under British (colonial) rule. Indigenous Africans earned more, were healthier, enjoyed more human rights and had a better life under Ian Smith than they did under Robert Mugabe.

I had lived through part of that colonial era, and wanted to voice my objection. If anything, the Zimbabwe that Mugabe had created was a direct result of the Rhodesia which Ian Smith had created. And if anything, Mugabe simply continued the imperial colonising state mechanism process he had inherited. The country's present woes could not only be traced to the incompetent and selfish government of ZANU (PF) but what they inherited from their predecessors - the Land Act, for example, and the State of Emergency Ian Smith had imposed in 1965, and which was never revoked, even twenty years after independence.

There was another motivation too. The slew of white memoirs and autobiographies coming out of Zimbabwe and an apparently self-righteous, whining and patronising tone of those whites who now considered themselves victims of the Mugabe regime after the farm invasions prompted me to 'put the record straight'.

In an article discussing Peter Godwin's 2002 memoir When a Crocodile Eats the Sun, Tony Simoes da Silva observes that in this autobiographical work (and in other neo-colonial, post-apocalyptic memoirs by 'white Zimbabweans') there is a 'seemingly harmless narrative turn, [in which] white Zimbabweans are absolved of any responsibility for their complicity in the creation of the present status quo. They are now only victims, rather than victims now but also perpetrators in the not too distant past' (Simoes da Silva 2011). This 'moral turn', it seems, legitimates a righteous white anti-Mugabe rhetoric, which looks suspiciously similar to old racist Rhodesian rhetoric. In writing my memoir, it would have been easy for me to follow the pattern of many of these memoirs and lapse into an anti-Mugabe tirade, or easier still, into some childhood Edenic nostalgia about how wonderful it was to grow up in Rhodesia (which is what many readers of such memoirs expect). To tell the truth of 'white' intervention in this country from the inside, I wanted to show that it was not better for indigenous people or, for that matter, for white people who did not consent to the racist rhetoric of the times. Doris Lessing, for example, a 'white Rhodesian' was persona non grata in that country for twenty years, and could not return until 1980. If I was going to be completely honest, I would also probably have to confess that I did live in a cosy idyllic past of racist rhetoric, and was quite at home there, for a while at least.

As for narrative technique, honesty was my method, if honesty can be called a method. In the attempt to put the 'record straight', to get to the 'real truth' about the Rhodesian conflict, I had to recall, as honestly as possible, my experience of growing up in this British colony from 1960-1980.

And on the book's publication, honesty as a theme was highlighted by both readers and critics:

'A vivid story of coming of age in a country falling apart, told with wry, dry, self-deprecating honesty.' (Le Guin 2008) 
'A lucid, insightful and unflinchingly honest account of what it was like growing up during the last days of white rule.' (Stidolph 2008a)

'The uncompromising honesty of the author, and the pageturning power of the story, will reward almost any reader.' ('Peter H' 2009)

'His book is also more than just the usual nostalgic trawl down memory lane. For one thing he is too honest.' (Stidolph 2008b)

I believed in honesty, in truth, and in the enterprise of memoir, which I took to mean interrogating memory and personal experience to get to that truth. Hence the two epigraphs I placed at the beginning of the book:

The people who fought in that war and know what it was like are in their twenties and thirties. Soon at least some will be writing their memories, autobiographies, reminiscences. Then the truth about the War will be exposed, and there will be two versions, the official histories and the truth. Doris Lessing, African Laughter (1993)

A true war story is never about war. It's about sunlight. It's about the special way that dawn spreads out on a river when you know you must cross that river and march into the mountains and do things you are afraid to do. It's about love and memory. It's about sorrow. It's about sisters who never write back and people who never listen. Tim O'Brien, The Things They Carried (1990) (Williams 2008: ii)

Little did I know how ironic these quotes would become as I began to write.

\section{Narrative strategies}

The first problem in using memory as the basis for my research methodology or as a narrative strategy is that my experience of Rhodesia 1960-1980 was somewhat false, if not totally illusory.

In an interview in a Zimbabwean literary journal Mazwi, I was asked: 'What was it like growing up in Rhodesia?' to which I replied, surprising myself at being able to articulate it for the first time in such stark terms:

Growing up white in Rhodesia was quite simply a lie: whites lived in a bubble of propaganda. White Rhodesia was not Africa: it was England in the tropics. It ignored African cultures and history, and made African people invisible. At school I learned Latin, French, and Italian, but not a word of Shona or Ndebele. From my peers, I learned racism and sexism and arrogant myopia. I had a very privileged upbringing, and it was not until I was called up to fight in the Rhodesian army that I began to see through the façade of this 'Western Christian Civilisation' and experience the horror of war. The memoir chronicles my attempt to disentangle myself (unsuccessfully) from being 'Rhodesian' and from fighting in the war. (Mushakavanhu 2011) 
I had grown up in a propaganda bubble of a white supremacist rhetoric, much like that of Nazi Germany: a state of emergency, press censorship and U.N. sanctions had effectively shut me off from the outside world, and my own perceptions had been constructed for me by a monolithic white colonial media. But then, if I had denounced my white Rhodesian self, who was I? The interviewer pressed me to elaborate on my sense of 'white' self:

\section{The ZANU (PF) rhetoric is to treat any [white] Zimbabwean with suspicion or label them as die hard Rhodies. What defines identity and nationality?}

Theoretically race should play no part in national identity. You cannot help being born white or black, and therefore this must not exclude you from your birthright to be Zimbabwean. To say, as some people do, that whites are not Zimbabweans is to use the same racist reasoning used by Ian Smith's Rhodesians to exclude blacks from political rights - skin colour. So we have to get away from race in defining identity or nationality. But of course we can't. Being white or black connotes a whole lot of historical and political baggage. We have not integrated our society enough to ignore skin colour. (Mushakavanhu 2011)

So if I was to be really honest, all I could do was interrogate those perceptions and examine how this white Rhodesian male self had been constructed. But to do this, I needed access: I had to be outside of it; I had to have hindsight; there had to be gaps through which the reader and I could peep, because the protagonist of the memoir, a naïve young version of me, was much too fervently racist and arrogantly self-assured in his white-supremacist world view to help in this project. History had been delivered to him in slabs of absolute truth. He was also arrogantly male with a firm belief in essentialist gender roles.

But early in the narrative, this protagonist is unsettled by the 'garden boy', an indigenous African servant who provides the protagonist ('Paul') with an alternative history to the colonial one he has learned at school, and which precipitates his political education.
"So who were these evil people-without-knees?" I asked. "Who was this Lodzi? Did you throw him out?"
"It has begun," Chelogue said. "For a long time, the people were asleep, but now they are waking. They will throw the kneeless people out, and will have the land back again. Again it will be paradise, clean blue skies, clean rivers and proud spirits." (Williams 2008: 20) [1]

At the time, however, Paul does not understand that he is the 'evil' coloniser referred to in this alternate history, and this provides the older narrator the irony necessary to lever a more honest truth from his self-deceived, unreliable narration. And when the protagonist presses the servant on his methods for ridding the country of this evil oppressor, the gardener says:

"You don't fight a crocodile by stabbing its nose with a thorn." And he laughed a hoarse cougher's laugh, scaring Jaqi and me a step back. "You have to wait until it sleeps then you worry it constantly so it cannot sleep or rest until it gets uncomfortable. You can't kill it, but you can drive it into the sea." (47) 
The second 'gap' in the protagonist's colonialist ideology is provided by Paul's neighbour, a six year old girl who calls herself 'Jaqi'. She takes it upon herself to educate the protagonist about sexuality, and proposes her own counter-myth to patriarchy:

"Do you know why my brother has a willy?" she asked me. "And my Dad, too?"

I shook my head...

"It's like Pinocchio," she said. "When he told lies, his nose grew. Same with Drew and my dad."

I thought of Jaqi's dad, shouting and hitting the kids, drinking beer, using his colourful language...

"Bad people grow willies." She stared at the silence shrouding me, and I swallowed. "It's true," she said, mistaking my discomfort for incredulity. "Don't you believe me? And the badder they are, the longer their willies get."

...Now of course, her next question was, did I have a willy, and if so, how long was it? Suddenly it was time to go home. Bathtime. I beat my hasty retreat, but Jaqi followed. She never had to take baths, she said, but would like to see me take mine. My mother was not an ally. "Of course Jaqi can sit in the bathroom. Does she want to get in too?" Shit, no, Jaqi was not prepared to go that far. But she sat on a chair and I had to lie face down the whole time she was there. She was watching carefully but I never moved, even when the water grew cold, so cold I was goosy and told her to go. "Oh, well, it's suppertime, I suppose." (30-31)

Paul's complicity as a white, male coloniser early in the memoir precipitates his identity crisis further in the narrative. [2] But only as I began writing the second part of the book did I realise that I was doing more than simply exposing this complicity: I was also creating a past identity. Leigh Gilmore in The Limits of Autobiography: Trauma and Testimony (2001) suggests that what memoir and autobiography does is not so much describe a 'real' past, but a 'textual space wherein the culturally constructed and historically changing epistemology of the self finds particular expression' (Gilmore 2001: 85). Further, 'the autobiographical self owes its existence to the system of representation in which it evolves and finds expression' (85). I was not unearthing the past, or even 'setting the record straight' or 'showing what really happened' as I had initially thought: I was excavating how a 'self' had been shaped by the language of propaganda.

The second problem I faced in recounting 'The Truth' was that my initial research methodology (dredging up memories and recording them down as accurately as possible) did not yield any fruitful results. Not only were my memories unreliable, constructed and false: they were also trivial. There was a war going on, and I was unaware of it. The British Empire was breaking up, and I had no idea. All I could do then was to record these memories in ways that revealed their unreliability and that exposed them as fictional constructs:

They [my parents] arrived in Rhodesia, the story goes, with a pram full of saucepans, a few shillings jangling in their pockets, and an optimistic trust in a benevolent universe, that 
things would somehow work out. That's how they tell it, anyhow. (Williams 2008: 6, italics added)

To expose the 'gaps' and contradictions in the propagandist narrative, I brought in another fictive prop - the frame-narrator: an older, wiser 'Paul' who could 'tell the truth' about what was 'really' going on, who could see the chinks in this monolithic colonial discourse. The difference between the two, I hoped, would create an ironic discrepancy between the two of them.

My first memory apparently is a stark image of the white bars of my cot, a square, mauve wallpapered room... I am also told that I waved goodbye to my mother every morning as she guiltily drove off to work... But I really only remember from about the age of four onward, and I only remember insignificant fragments of my life in media res... It worries me how trivial these memories are. I didn't remember anything important, like the time I was lost and then found in the servants' kaya, eating sadza with them, to the wrath of my parents. I didn't know about the riots in the townships, the breakup of the Federation which had brought us here in the first place, or the crisis when my parents almost returned home with a pension, but then bravely stuck it out. I didn't know about the fear that oozed out of the white population at the breakup of the Great British Empire, the surrender of power, the flight of whites, and the triumph of independent dancing Africans in certain countries to the north of us. (11, italics added)

Again, I was naïve. The older narrator was just as prone to the inaccuracies of recollection, biased perceptions and errors of the younger narrator. All I had done was impose another way of seeing, one more accessible to the reader perhaps, but nevertheless flawed with the same poverty of perception.

But what was most surprising to me was that the act of writing memoir forced me to use an array of narrative and critical strategies so similar to that of writing a fictional work that it became difficult to distinguish the two. I had already decided on an unreliable narrator and had added a frame narrator. But now more consequential narrative choices had to be made: I wanted the myriad of people in my childhood to be condensed in manageable and memorable characters, primarily because one literary agent complained that my memoir had (like Mozart's music with too many notes) 'too many characters'. I wanted the narrative to follow a Freytag's pyramid plot structure with its precipitating crises, climaxes, denouement and cathartic resolutions; I had to be selective in my material in order to shape the essential story. But by imposing a complex fictional structure on the memoir, I had now blurred the distinction between fiction and non-fiction. I was fortunate in that Rhodesian/ Zimbabwean history propagandists had already provided me with a fictive narrative structure for my memoir. Both the British colonists and African nationalists in Rhodesia had fictionalised their own struggle (especially the years 1960-1980) in terms of a myth of rise and fall, and this coincided with my parents' call to adventure, hamartia and subsequent anagnorisis:

When my parents decided to go to Africa in September 1958, they didn't know they were stumbling into the beginnings of a civil war that would spiral into political madness, and end in economic ruin and poverty. They didn't know that their only son would be coerced into fighting in the war. Nor did they know that in the early hours of the new millennium, they would have to flee the Dark Continent, leaving their house, car, 
servant, bank account, and forty-six-year old suntan. (Williams 2008: 5)

And as I wrote the memoir, for the sake of narrative unity, I was compelled to fictionalise more and more. People in my past became protagonists, antagonists, heroines and heroes; I created composite characters made up of many people; places were compounded into one or two central locations; three places became one; ten trips to the frontline of the war became three; I invented conversations, dialogues and exchanges that could not possibly be historically accurate or remembered in their entirety; I changed names of actual people so as not to offend or incur their wrath; I borrowed rhetorical devices from Vladimir Nabokov, JM Coetzee, Martin Luther King, from Zulu praise-poetry. My narrative was now looking less and less a memoir and more and more a fiction, a mock-memoir. But I dogmatically maintained that I was still accountable to 'truth' ('truth' of course in inverted commas), and so added a disclaimer at the front of the memoir, inspired by Azar Nafisi who had liberally changed names and events in her memoir to protect the people she wrote about:

\section{DISCLAIMER}

Although this is a memoir and strives to give a 'true' account of the narrator's life, certain events, characters, and characters' names have been changed / blended together to protect identities, and to telescope history into manageable proportions. As Azar Nafisi says in her Author's Note to Reading Lolita in Tehran, 'The facts in this story are true insofar as all memories are true'; that is, all history is fictionalised, second-hand, and transmuted by the act of writing into the language of myth, dream and metaphor. (vii)

Had I now moved out of the realm of memoir into historical fiction? Or historiographical metafiction? Maybe I should simply call this a 'novel' and have done with it.

\section{Emotional truth}

And what of the historical inaccuracies, the 'stretchers', the distortions I had made to achieve narrative unity? After publication, literalist readers were quick to point these out: why did your protagonist see a Green and White flag on a building in 1965 when that flag was only issued in 1970? Why did you suggest that the Green Leader massacre took place in 1977 when it actually happened in October 1978?

The answer I told myself was that I was writing 'Emotional Truth.' According to Murdock, we just have to be taken in good faith, and try our best to recollect the events described:

We each have our own emotional truth. That truth might not be exactly factually correct, but what is important for the person writing memoir is how they recall the event and what meaning they make out of it for their lives. I don't mean, in any way, that they fabricate the event. What I mean is that they take an actual event and replicate it to the best of their recollection. (Murdock 1982: 1)

Or further, 
Perhaps it never did snow that August in Vermont; perhaps there never were flurries in the night wind, and maybe no one else felt the ground hardening and summer already dead even as we pretended to bask in it, but that was how it felt to me, and it might as well have snowed, could have snowed, did snow. (Didion 1969: 2)

Or perhaps the facts do not matter at all: 'What happened to the writer is not what matters; what matters is the larger sense that the writer is able to make of what happened' (Gomick 1996). As Ken Kesey's narrator of One Flew over the Cuckoo 's Nest suggests: 'It's the truth, even if it didn't happen' (Kesey 1962: $1)$.

But 'emotional truth' destabilises the very idea of a retrievable, verifiable past and excuses the writer from accountability to historical fact. Readers cannot rely on emotional truth to find out 'what really happened'. The line between fiction and non-fiction has been crossed. And how then could my memoir be regarded as 'honest'? I had deceived the critics (and myself) with my rhetorical device of confessional honesty.

If Soldier Blue is then about how 'truth' is constructed, or further, how my protagonist's distorted, biased, white colonial truth is constructed, then this was not memoir at all I was writing but the subversion of memoir. Perhaps by sacrificing (apparently) historical and factual integrity for the achievement of other aims - that of achieving the emotional truth of the memory/event, and of attempting to loosen Rhodesia's hold on my protagonist from the confines of gender/race/class - I had not written a memoir; rather I had inhabited the genre of a memoir in order to demythologise history and tease out the idea that memoir itself is a false construct. And perhaps it is in this way that Soldier Blue was deemed honest.

But I was not convinced that 'emotional truth' - which has an indulgent, subjective quality that bothered me - was an argument I could use. Like many Southern African writers, I was committed to accountability, to History, to the Struggle. In the context of the political struggles in Zimbabwe and South Africa of the time, there was a general consensus that writers had to be engaged, promote activist agendas, write protest literature and generally be on the 'right side' of history.

A speech JM Coetzee delivered at a literary conference in 1987 helped free me from both the swamps of emotional truth on the one hand and the unexamined, unquestioning idea of History as Truth on the other. In the context of a debate regarding the prescriptive social realism of South African literature of the 1980 s, Coetzee described the act of writing itself as by its very nature a mythologising act, and he envisioned a kind of fiction freed from the confines of 'history':

...a novel that operates in terms of its own procedures and issues in its own conclusions, not one that operates in terms of the procedures of history and eventuates in conclusions that are checkable by history (as a child's schoolwork is checked by a schoolmistress). In particular I mean a novel that evolves its own paradigms and myths, in the process (and here is the point at which true rivalry, even enmity, perhaps enters the picture) perhaps going so far as to show up the mythic status of history - in other words, demythologising history. (Coetzee 1988: 2-3) 
The 'truth' of my memoir then was not to depict history, or even to supplement history, but rather to demythologize history.

\section{Self-erasure}

The more I wrote, the more I understood the trajectory of the book. Towards the end of the memoir, when I struggled in vain to give meaning to the contradictory strands of my protagonist's path, I realised that perhaps this was the point, and that my protagonist mirrored the contradictory trajectory of what Albert Memmi (1990) calls the 'Coloniser who Refuses' (106). According to Memmi, the 'left-wing colonising' subject is a contradiction in terms who can occupy no space, who is caught up in his own semantic self-reflection, and whose (authentic) identity is not possible.

Memmi presents two options for the coloniser who refuses: either he stays to fight for justice, or has to leave and return to his home country. But Memmi makes clear that the first option is not possible: the coloniser cannot surrender his identity and privilege. In fact, the act of protesting can only arise from his privileged position of power. The only way the coloniser-who-refuses can achieve his goal of overturning his own position and identity is to become some kind of self-sacrificing Promethean hero ('our man would have to be a moral hero' 107).

Soldier Blue was becoming a story of self-erasure, the dismantling of a colonial self (a 'kneeless-Lodzi-crocodile-Pinocchio'), and the language systems the protagonist used to create his identity.

The solid colonial identity of the protagonist begins to crack when he is conscripted into the Rhodesian army, and he finds it necessary to distance himself from the atrocities his fellow soldiers are committing. After witnessing (and therefore being implicated in) a torture session, he writes an imaginary letter to a torture victim's sister:
Dear Nomsa
It will be all right. He'll be OK. You see, I'm a medic, a madoctor, who is trained to heal, to protect and serve, to clean up the mess after the Major has gutted and spilt blood. But he's penga, that man. Penga, you understand. Look at the distance I am demarcating: him ... me ... you. You want me to warn you next time? Next time is tonight, tomorrow, every day. Major Madoxes and white soldier ants are crawling all over the soft, black skin of this country. (Williams 2008: 253)

But he cannot distance himself: he is the coloniser; he is the soldier with the rifle; he is the privileged white male, and that as the gardener pointed out earlier to his child self, the enemy is himself: 'The enemy was our own human nature, red in tooth and claw, our masculine propensity for violence and destruction' (379).

Finally, in his attempt to create a space for himself, the protagonist takes a 'heroic' stand against his superior officer: it's an act of self-obliteration and futility, an attempt to eradicate his Rhodesian colonial white male self, but he is easily outmanoeuvred and dismissed. It is nevertheless that heroic Promethean gesture, and according to Memmi, the only recourse he has:

"M... M... Major Madox (it was a pity about the stutter), I am charging you with obstruction of my medical duty. This report 
is going straight to my C.O. in Llewellyn Barracks, and then on up to the Commander of Llewellyn and D.R.R." I waved the piece of paper in his face. I was conjuring up judgment day... "I'm also charging you with conspiring to subvert justice, with manslaughter, and..."

I got no further. Major Madox lunged across the table and ripped the paper from my hand. I didn't quiver or cower, though I feared he would spring at my throat like a bulldog. But he did not strike me. He held the paper at arm's length to read (he did not have his glasses on), and then tore it up in three slow movements.

"Doc, you know sweet fuck all about what we're doing here."

"You're right."

"I know you. You want us to lay down our arms and give up. Here, comrades, take over the villages, the T.T.L.'s, the country. Help yourself. Murder, maim, kill your own people. Go ahead. Over my dead fucking body!" (385)

This defeat, though predictable, is the only moral position he can take. The coloniser-who-refuses has to accept his own insignificance, because his aim in overthrowing colonialism will overthrow himself: 'Colonial relations do not stem from individual good will or actions; they exist before his arrival or his birth, and whether he accepts or rejects them matters little... The end of colonisation ... can result in the overthrow of his own situation and himself' (Memmi 1990: 106).

Even the act of protest - speaking against a regime, or on behalf of the colonised - is using power and privilege, claiming a territory and assuming the self- importance of a coloniser. The only way, it seems, to decolonise the white colonial 'self' is by abdication, self-obliteration and silence.

After independence, I took care to purge any Rhodesianness from my being. I became 'Zimbabwean'. I was pardoned for my sins, I became a comrade, and I obliterated my past. Like me, Rhodesia was no more. It was an illegal entity whose years $1965-1980$ had ceased to exist. I too was an illegal entity whose life 1965-1980 had ceased to exist. (Williams 2008: 241)

JM Coetzee's narrative project, particularly in his early novels, similarly explores a colonising subject's attempts at both self-definition and selfobliteration. The second half of his first novel Dusklands (1974) is a fictional autobiography of the author's ancestor, Jacobus Coetzee, a Dutch settler who ventures into the interior of a pre-colonial South Africa, massacres indigenous people, and celebrates his identity as a Cartesian divided self - as a coloniser:

The whites of South Africa participated, in various degrees, actively or passively, in an audacious and well-planned crime against Africa. Afrikaners as a self-defining group distinguished themselves in the commission of that crime. Thereby they lent their name to it. It will be a long time before they have the moral authority to withdraw that brandmark... Is it in my power to withdraw from the gang? I think not... More important, is it my heart's desire to be counted apart? Not 
really. Furthermore - and this is an afterthought - I would regard it as morally questionable to write something like the second part of Dusklands - a fiction, note - from a position that is not historically complicit. (Attwell 1992: 342-343)

Likewise, the protagonist in Soldier Blue cannot disentangle himself from his constructed identity, but rather acknowledge that he is morally and historically complicit. And to refuse means to articulate that refusal.

It is hard to believe that these roads, small and tattered, once ran with dreams of pursued white goddesses, and that the self I am attempting to retrieve from here is a petty, insignificant one who played no role in history, except to be one of the many whites trapped in a box, thinking they were at the centre of the world.

There are thirteen million people in Zimbabwe at this time, nearly three times the population of 1971 . The whites constitute an irrelevant 0.1 per cent. Even in 1971, with the white population at 2.5 per cent, we were a tiny minority. How did we presume such significance? (400-401)

This idea of invisibility and self-erasure in white colonial, particularly Southern African writing, is not new, but is not always thus self-imposed. Breyten Breytenbach's Dog Heart: A Memoir (1998) articulates the fear of erasure as a loss of identity and politico-historical consequence: 'We [whites] are painted in the colours of disappearance' (Breytenbach 1998: 151). His earlier memoir, The True Confessions of an Albino Terrorist (1984) similarly explores the impossible space of white dissenter. JM Coetzee's Waiting for the Barbarians (1982) documents a fictional self-abdicator, the Magistrate, a Memmian coloniser-who-refuses, but ultimately cannot accept his erasure from history. Abdication of that morally righteous white colonising self was a necessary step in finding the 'truth', the 'honesty' of my life. But this led to another contradiction. If I was abdicating my position as coloniser, as controller of a master discourse, then why was I writing a memoir (occupying that space) at all?

Gillian Whitlock proposes that 'the first question we should ask of a memoir is not "why is this person's life an important or distinguished one?" but "what is the place of this writer in this culture...?"” (as cited in Buss 2001: 595). And as 'memoir is the prerogative of those who possess cultural capital' (Whitlock 2007: 20-21), writing an abdication of self feels contradictory because the act of writing memoir is an act of self-iteration, of legitimating a place for one's self.

In the same interview referred to earlier, Tinashe Mushakavanhu, Zimbabwean writer and academic, honed in on this contradiction. If it was necessary for colonised subjects of Zimbabwe, in Ngugi wa Thiong'o's words to 'decolonise the mind' (Ngugi 1986), then how much more necessary was it for colonising subjects?:

Interestingly, you introduced yourself to me in an email as an [ex?] Zimbabwean writer. What are you then?

The memoir chronicles my attempt to disentangle myself (unsuccessfully) from being 'Rhodesian' and from fighting in the war. At university, I took quite a radical anti-white stance, and felt that because of my 'whiteness' I could not be expected 
to be accepted by black Zimbabweans just as I was. I could not sweep my whole racist, privileged past under the carpet: I felt I needed to 'decolonise my mind', to use Ngugi's phrase, or become the "colonizer who refuses" [to use Memmi's phrase]. (Mushakavanhu 2011)

I had found it impossible to simply chronicle the past, or bear witness to atrocities, or to protest injustice, and my memoir had become, in JM Coetzee's words, an attempt to 'dissect the myths of our culture'. [3] Acknowledging that the act of writing itself was an act of colonisation, writing memoir for me had to be an act of critiquing memoir itself.

What of my claim or my intention that through this process, I was 'liberating the 'I' or 'self' from the confines of gender/race/class'? It seems rather that I had written about the impossibility of escaping these confines, and deconstructed how the prison of language had confined this colonising self to that discourse.

But if, as Fredric Jameson suggests, our access to history is always textual, then the act of writing can be seen not as a colonising act of appropriation, but could itself become a liberation from the discourse of History (Jameson 1982).

In grappling with these issues, I turned to South African white writers to see how they had dealt with this problem. White South African literature has primarily been protest literature, a vehicle used to expose the injustices and atrocities of the Apartheid regime and its ideology. Andre Brink's A Dry White Season (1979), for example, shows a white liberal what life is like for black people in the townships outside his protected white suburbs. A Dry White Season depicts a coloniser who refuses, but one who simply protests against injustice, and whose power and moral authority resides in his writing as a way to 'set the record straight' - or in Brink's words, 'a matter of making sure the people knew about it, and were forced never to allow themselves to forget it' (Davidson 1984: 24). His identity remains morally intact. Similarly, Nadine Gordimer's white protagonists can be 'saved' from their complicity with the Apartheid regime by siding with the oppressed and, somewhat unproblematically, renouncing their white privilege.

But JM Coetzee in his South African novels exposes the lie of the white liberal who can appeal to a universal justice, and argues how even the discourse of protest is an act of colonisation. For Coetzee, writing itself is an act of complicity, and each of his narratives casts doubt on the validity of the act of writing to protest injustice. In his first trilogy of novels (Dusklands, In the Heart of the Country, Waiting for the Barbarians) Coetzee investigates the nature of the white coloniser in Cartesian terms. In Dusklands, for example, the white protagonist is a coloniser-who-accepts, a Cartesian 'self' (pure consciousness, mind, intellect, the masculine) who deliberately severs his connection to 'other' (the colonised, the land, the body, the feminine). Waiting for the Barbarians documents the futile attempt by such a coloniser (the Magistrate in this case) in an unnamed and ahistorical Empire to put the two Cartesian halves together again and reconnect himself to the colonised, to the land, and to the female 'other' (in this case a Barbarian 'girl' who has been captured and tortured and whose body he tries to heal). Instead he realises that he is simply a mirror image of the Empire: 'The distance between myself and her torturers, I realize, is negligible' (Coetzee 1982: 27).

But where does that leave the 'coloniser-who-refuses'? In an article comparing Coetzee's novel to Nadine Gordimer's July's People (1981) - an apocalyptic exploration of the white liberal's plight in South Africa - Paul Rich argues that 
whereas Gordimer's characters integrate into society, accept and are accepted into a liberal ideological agenda, in Coetzee's novel:

...the magistrate - in his move toward rejection of empire becomes an example of what Albert Memmi has termed 'the coloniser who refuses'. Insofar as he is still part of the imperial 'civilisation', the magistrate merely cuts himself off from his fellow imperialists and comes to represent merely himself. (Rich 1984: 1)

In a similar way then, Soldier Blue is a memoir whose agenda is to expose the fallacy of liberating the 'I' or 'self' through the act of writing. Yes, like Andre Brink's novel, it speaks truth to power, and sets the record straight. But has it liberated the 'I' or 'self' from the confines of gender/race/class? At the end of the memoir, the narrator is still a white, colonial and most of all complicit Rhodesian self, albeit a 'coloniser-who-refuses'.

Ultimately, Soldier Blue is a memoir about mythologising and demythologising history, constructing memoir in order to deconstruct the concept of memoir, analysing discourse while using that discourse, and most contradictory of all, creating a space in which to assert a self in order to deny that self and erase that space. And it does this by asserting the primacy of fiction as its primary narrative device.

\section{Notes}

[1] The British colonisers were known to the native people as 'kneeless' because of the long khaki shorts they wore that covered their knees. 'Lodzi' is Cecil John Rhodes whose forces in 1890 occupied the country on behalf of the British Empire. return to text

[2] There is of course the issue of speaking on behalf of the silenced and disempowered, 'putting words' in the mouths of 'black' characters. I decided to tar all my characters with the same brush. No one in the memoir speaks truth (as in objective, journalistic truth). So while Chelogue's and Jaqi's counter-myths oppose the myth-making of white male Rhodesia, they are not meant to be the 'real' yardstick by which readers can measure truth. Chelogue's account of pre- and post-colonial Zimbabwe is fanciful and idealistic ('paradise, clean blue skies, clean rivers and proud spirits' [20]). Jaqi's understands the nature of patriarchy by using a fairy-tale. And further, the narrator's self-enclosed account of his past cannot allow him to speak for authentic African voices or for women. Chelogue and Jaqi are both imposed images of 'the other'. Chelogue first appears in the narrative as an alien ('take me to your master,' he says, and gives an unpronounceable name when asked, and so is christened by Paul with the first 'African' word he has learned, chelogue, the name Paul thinks is Shona for penis (the unsightly, 'wrinkled squatter in the corner of the garden' [31]). return to text

[3] Olsen quotes JM Coetzee as saying: 'some cultural artefacts reinforce the myths of our culture, others dissect these myths. In our time and place, it is the latter kind of work that seems to me more urgent' (Olsen 1985: 47). return to text

\section{Works cited}

Attwell, D 1992 Doubling the Point: Essays and Interviews, Harvard University Press, Boston return to text

Boynton, G 2007 'Ian Smith has sadly been proved right', The Daily Telegraph, London (22 November): http://www.telegraph.co.uk/comment/3644217/Ian-Smith-has-sadly-been-provedright.html (accessed 20 June 2012) return to text 
Breytenbach, B 1984 The True Confessions of an Albino Terrorist, Farrar, Strauss \& Giroux, New York return to text

Breytenbach, B 1998 Dog Heart: A Memoir, Faber \& Faber, London return to text

Brink, A 1979 A Dry White Season, WH Allen, London return to text

Buss, H 2001 'Memoirs', in The Encyclopedia of Life Writing, ed M Jolly, Fitzroy Dearborn, London: 595-597 return to text

Coetzee, JM 1988 'The Novel Today', Upstream 6, 1 (Summer): 2-5 return to text

Coetzee, JM 1982 Waiting for the Barbarians: A Novel, Penguin Books, London return to text

Davidson, J 1984 'Interview with Andre Brink', Overland 94-95: 24-30 return to text

Didion, J 1969 'On Reading a Notebook', Slouching Towards Bethlehem, Andre Deutsch, London and at http://www.ranablog.com/pdfs/didion.pdf (accessed 4 November 2012) return to text

Gilmore, L 2001 The Limits of Autobiography: Trauma and Testimony, Cornell University Press, Ithaca, NY return to text

Gordimer, N 1981 July's People, Jonathan Cape, London return to text

Gornick, V 1996 'Why Memoir Now?' The Women's Review of Books 13, 10/11: 5

Jameson, F 1982 The Political Unconscious: Narrative as a Socially Symbolic Act, Cornell University Press, Ithaca, NY return to text

Kesey, K 1962 One Flew over the Cuckoo’s Nest, Viking, New York return to text

Le Guin, UK 2008 Back cover review, in P Williams Soldier Blue, David Philip Publishers, Cape Town return to text

Lessing, Doris 1993 African Laughter: Four Visits to Zimbabwe, Flamingo, London return to text

Memmi, A 1990 The Coloniser and the Colonised, Orion, London return to text

Murdock, M 1982 'Interview’ with B Lynn Goodwin, Maureen Murdock:

http://www.maureenmurdock.com/emotionaltruth.html (accessed 4 June 2012) return to text

Mushakavanhu, T 2011 'White Rhodesia was not Africa: it was England in the tropics', Mazwi (30 October): http://www.mazwi.net/interviews/interview-white-rhodesia-was-not-africa-itwas-england-in-the-tropics (accessed 1 June 2012) return to text

Nafisi, A 2003 Reading Lolita in Tehran: A Memoir in Books, Random House, New York return to text

Ngugi wa Thiong'o 1986 Decolonising the Mind: the Politics of Language in African Literature, Heinemann, London return to text

O’Brien, T 1990 The Things They Carried, Houghton Mifflin, New York return to text

Olsen, L 1985 'The Presence of Absence: Coetzee's Waiting for the Barbarians', Ariel: A Review of International English Literature. 16, 2: 47-56:

http://ariel.synergiesprairies.ca/ariel/index.php/ariel/article/view/1887 (accessed 20 June 2012) return to text

'Peter H’ 2009 'Soldier Blue deserves a wide readership', amazon.com.uk (3 May): http://www.amazon.co.uk/review/R1VZ9204A34O00 (accessed 25 April 2013) return to text

Rich, P 1984 'Apartheid and the Decline of the civilization Idea: An Essay on Nadine Gordimer's July's People and JM Coetzee's Waiting for the Barbarians', Research in African Literatures 15, 3: 365-93 return to text

Simoes da Silva, T 2011 'Longing, Belonging, and Self-making in White Zimbabwean Life Writing: Peter Godwin's When a Crocodile East the Sun', LinQ 38 
http://www.linq.org.au/samplers/articlefiles/JCUPRD1_069427.html (accessed 20 June 2013) return to text

Stidolph, A 2008a 'Best Reads of 2008', Weekend Witness Pietermaritzburg, South Africa (28 November): http://www.witness.co.za/index.php?showcontent\&global\%5B_id\%5D=16595 (accessed 4 February 2013) return to text

Stidolph, A 2008b 'Wry and Compelling', The Witness, Pietermaritzburg, South Africa (17 December): http://www.witness.co.za/index.php?showcontent\&global[_id]=17438 (accessed 4 February 2013) return to text

Unattributed 2006 'A Million Little Lies: Exposing James Frey's Fiction Addiction', The Smoking Gun (4 January): 2006 http://www.thesmokinggun.com/documents/celebrity/millionlittle-lies (accessed 14 June 2012) return to text

Whitlock, G 2007 Soft Weapons: Autobiography in Transit, University of Chicago Press, Chicago return to text

Williams, P 2008 Soldier Blue, David Philip Publishers, Cape Town return to text

Paul Williams has a PhD in Creative Writing from the University of Wisconsin, USA and lectures in Creative Writing at the University of the Sunshine Coast. He has published young adult novels, a memoir, educational readers, short stories and critical articles, and his books have been set in schools across Africa. The Secret of Old Mukiwa won the Zimbabwe International Book Fair award for Young Adults in 2001 and Soldier Blue won Book of the Year in South Africa, 2008. His stories have appeared in Meanjin (Australia), Chicago Quarterly Review (USA), New Writing (UK), New Contrast (South Africa) and Mazwi (Zimbabwe).

\section{TEXT}

Vol 17 No 1 April 2013

http://www.textjournal.com.au

General Editor: Nigel Krauth. Editors: Kevin Brophy \& Enza Gandolfo text@textjournal.com.au 